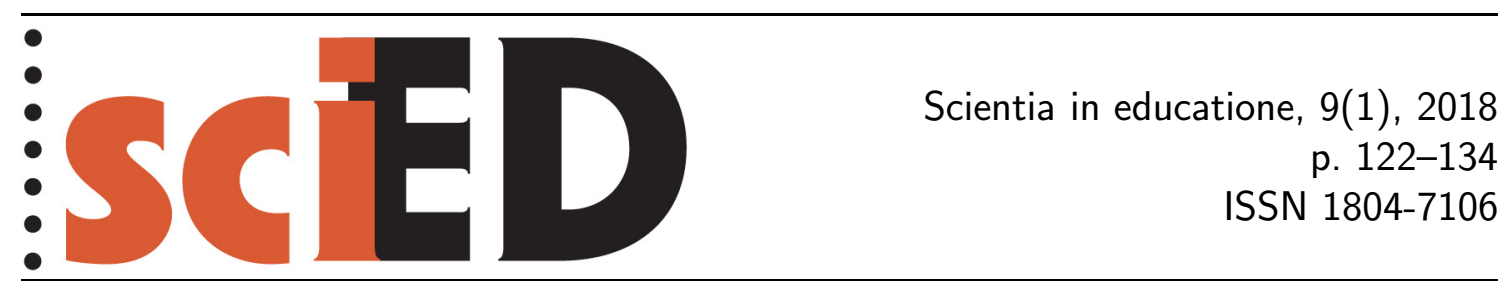

\title{
Proměny fyzikálního kurikula - první výsledky analýzy mezinárodních zdrojů
}

\author{
Vojtěch Žák, Petr Kolár
}

\begin{abstract}
Abstrakt
Cílem této studie je charakterizovat pojem kurikulum a prezentovat vybraná výzkumná zjištění, která jsou využitelná při proměnách fyzikálního kurikula střední školy. Pojem kurikulum nabývá různých významů. Patří k nim obsah vzdělávání, vzdělávací plán a nejobecněji obsah veškeré zkušenosti, kterou žáci získávají ve škole a v činnostech ke škole se vztahujících. O významech a složitosti tohoto pojmu vypovídají jeho dimenze - ideová, obsahová, organizační a metodická. Kurikulum existuje také v různých formách - koncepční, projektové, realizační, rezultátové a efektové. Cúlem rešerše v databázích SCOPUS a Web of Science bylo vyhledání studií, které popisují proměny fyzikálního (resp. science) kurikula, a identifikování metod, které jsou použivány při tvorbě nových kurikul. Výsledkem rešerše je mimo jiné zjištění, že výše zmíněných studií existuje v mezinárodním prostředí velmi omezený počet. Přesto rešerše přinesla některá zjištění, která mohou být využitelná při př́padných proměnách fyzikálního kurikula. Dalšími identifikovanými problémy jsou např. nízká matematická úroveň žáků omezující jejich fyzikální vzdělávání a poukazování na to, že reformy kurikula často spočívají pouze v malých úpravách původního kurikula.

Klíčová slova: kurikulum, didaktika fyziky, fyzikální vzdělávání, výzkum fyzikálního vzdělávání, střední škola.

\section{Changes in Physics Curriculum - First Results of Analysis of International Literature}

\section{Abstract}

The aim of the study is to characterize the concept of curriculum and to present selected research findings which may be useful when updating the physics curriculum of upper secondary school. The concept of curriculum may be understood in different ways. It may be seen as the contents of education, an educational plan and, most generally, as contents of all the experience pupils obtain at school and in activities connected to school. The meanings and the complexity of this concept are represented by its dimensions dimension of aims, content, organization and methodical dimension. The curriculum exists in various forms - conceptual, project, implementation, resulting and effective. The aim of the review part was to search for studies in databases of SCOPUS and Web of Science which describe changes of physics (respectively science) curriculum and to identify methods which are used when creating new curricula. The result of the review was, among others, the finding that the number of such studies is very limited in international environment. Another identified problem is, for example, the low level of pupils' mathematical knowledge which limits their education in physics. The investigated studies point out that the core of curriculum reforms lies only in minute changes of the existing curriculum. All these findings and some others may be used in prospective changes of physics curriculum.

Key words: curriculum, didactics of physics, physics education, physics education research, secondary school. 
Pojem kurikulum bývá používán v nejrůznějších souvislostech a nabývá několika významů. V oblasti vzdělávání ho můžeme v prvním přiblížení nahradit pojmem obsah vzdělávání (podrobněji dále v oddíle 1.1). Speciálně fyzikální kurikulum se v nedávné době celkem přirozeně vynořilo jako téma výzkumu a vývoje v souvislosti se zamýšlenou tvorbou nových učebnic fyziky pro české střední školy. Toto téma bylo pootevřeno $\mathrm{v}$ diskusích na katedře didaktiky fyziky Matematicko-fyzikální fakulty Univerzity Karlovy (dále: KDF MFF UK) před několika lety, a to mimo jiné v návaznosti na fakt, že stávající české středoškolské učebnice fyziky nemají ucelenou alternativu.

Zastáváme názor, že tvorba učebnic by neměla obnášet pouze řešení jejich konkrétního, v našem případě fyzikálního obsahu, ale měla by zahrnovat zejména úvahy nad cíli, ke kterým má vzdělávání podporované danými učebnicemi vést. Na druhou stranu oborový, tj. fyzikální obsah učebnic, je zcela zásadní a návrhy, co učebnice mají obsahovat, by se podle našeho názoru neměly omezovat na to, co v učebnicích nebo jiných kurikulárních dokumentech v současné době najdeme.

Tato studie je úvodním časopiseckým příspěvkem k tématu možných proměn fyzikálního kurikula, zejména na středních školách v České republice. K řešení tohoto tématu existuje pracovní skupina na KDF MFF UK, jejíž jádro tvoří autoři této studie, kteří jsou úzce spjati se vznikající disertační prací Východiska nového kurikula fyzikálního vzdělávání, která je řešena spoluautorem tohoto příspěvku (školitelem je V. Žák).

Cílem této studie je charakterizovat pojem kurikulum a prezentovat vybraná výzkumná zjištění vzešlá z mezinárodní literatury (včetně metodologie vyhledávání zdrojů), která jsou potenciálně využitelná při proměnách fyzikálního kurikula. Předložená studie, svojí podstatou přehledová, je určena především výzkumníkům v oblasti didaktiky fyziky, má ale ambici zasáhnout širší publikum - výzkumníky v oblasti didaktik dalších přírodovědných oborů a badatele v pedagogice. Obecněji je ale určena všem vzdělavatelům ve fyzice (tedy také učitelům na středních školách), kteří se zajímají o širší a hlubší souvislosti výuky, kterou vedou. Text je strukturován tak, že po části věnované vymezení pojmu kurikulum (oddíl 1.1), diskusi různých charakteristik kurikula (1.2 a 1.3) a specifik fyzikálního kurikula (1.4) je představena metodologie analýzy mezinárodních časopiseckých zdrojů, které pojednávají o proměnách fyzikálního kurikula (oddíl 2). Vybrané výsledky analýzy jsou obsahem oddílu 3 a výzkumné nálezy jsou dále shrnuty a diskutovány v oddíle 4 . V analýze časopiseckých zdrojů jsme se zaměřovali hlavně na proměny ideové a obsahové dimenze kurikula (viz 1.2), které považujeme za stěžejní pro tvorbu učebnic fyziky, ale byli jsme také otevřeni všem dalším (dle našeho názoru důležitým a užitečným) skutečnostem. Naší hlavní oblastí zájmu bylo fyzikální kurikulum pro střední školy.

\section{VYMEZENí POJMU KURIKULUM A JEHO CHARAKTERISTIKY}

\section{1 ÚVODNÍ VYMEZENí POJMU KURIKULUM}

Pojem kurikulum patří ke složitějším pojmům užívaným v oblasti vzdělávání a bývá charakterizován různými způsoby. ${ }^{1}$ Jak bude zřejmé z následujícího textu, hlavním

\footnotetext{
${ }^{1} \mathrm{~V}$ této souvislosti můžeme připomenout, že také v oblasti samotné fyziky jsou používány pojmy, které jsou vymezovány (definovány) různě a mají rozličné významy. Jako př́iklad můžeme uvést pole nebo pohybové rovnice.
} 
motivem jeho různých vymezení je obsah vzdělávání. Fakt, že se pojem kurikulum kryje s obsahem vzdělávání, je patrný z definic uvedených např. Maňákem a Janíkem (2009: s. 117), Průchou, Walterovou a Marešem (2013: s. 137) aj. Z těchto a dalších publikací je zřejmé, že se pojem kurikulum neomezuje pouze na obsah vzdělávání (příp. studia), ale že je obsah vzdělávání díky pojmu kurikulum zasazen do širších souvislostí.

Pojem kurikulum je mnohdy spojován s pojmy učební nebo vzdělávací plán např. Průcha (2017: s. 237), Roth (1991: s. 659) a německý termín Lehrplan; Průcha, Walterová a Mareš (2013: s. 137); Maňák a Janík (2009: s. 117). Kromě samotného obsahu je tedy zdůrazňován také průběh vzdělávání, jeho postup, časové hledisko. Zde je patrná souvislost $\mathrm{s}$ latinským curriculum vitae (průběh života). ${ }^{2}$

Pojem kurikulum však bývá chápan ještě šiřreji než jen jako obsah vzdělávání, jeho strukturování a organizování. Průcha, Walterová a Mareš (2013: s. 137) kurikulum vymezují jako obsah veškeré zkušenosti, kterou žáci ziskávaji ve škole a v činnostech ke škole se vztahujicích, jeji plánováni a hodnocení. Z tohoto vymezení je patrné, že si autoři uvědomují, že obsah výuky (obecněji vzdělávání) není vhodné nahlížet odděleně od dalších pojmů, jako jsou např. metody a formy vzdělávání, cíle vzdělávání atd., a odráží se zde zřejmě přesvědčení, že školní výuka, její podmínky, průběh a výsledky velmi úzce souvisí s činnostmi a okolnostmi, které se odehrávají mimo školu. $V$ přehledu a diskusi různých definic kurikula by bylo možné pokračovat dále, nicméně jeho význam bude diskutován v různých souvislostech v následujících oddílech.

\subsection{Dimenze KURIKULA}

Jedním z přístupů, jak strukturovaně řšsit otázky spojené s kurikulem, je jeho nahlížení v různých dimenzích (Maňák \& Janík, 2009: s. 118-119). Jak bude zřejmé $\mathrm{z}$ dalšího textu, dimenze $\mathrm{v}$ podstatě určují časovou posloupnost, $\mathrm{v}$ jaké by mohla být řešena tvorba nebo zásadnější proměna kurikula. Logicky první, ideová dimenze, zahrnuje cíle, ke kterým má vzdělávání vést. Tyto cíle jsou obecně závislé na společenské situaci, která bývá silně ovlivněna nejen aktuálním stavem daného společenství, ale je také závislá na historickém vývoji a na očekáváních (predikcích) budoucnosti.

Ideová dimenze zřejmě souvisí s filozofickými př́istupy ke kurikulu. Přehledově jsou tyto přístupy v domácí literatuře prezentovány Průchou (2017: s. 237-241). Ze zahraniční literatury pro srovnání uved’me např. Hendersona (1996), příp. Ornsteina a Levina (1989). Průcha (2017: s. 240) rozlišuje následujících pět filozofických přístupů ke kurikulu: akademický (také tzv. perenialismus), esencialistický, polytechnický, aktivistický (sociokritický, rekonstrukční, globální) a personální (progresivní). Pokud porovnáme charakteristiky cílů takto pojatých kurikul (srov. Průcha, 2017: s. 240), můžeme vysledovat, že některé př́istupy (a příslušná kurikula) jsou orientovány spíše na jedince a jeho individualitu (personální přístup), některé spíše na společnost jako celek (aktivistický, akademický). Určité přístupy čerpají spíše z historie a kultury dané společnosti (akademický), jiné se orientují na budoucnost a budoucí možné proměny společnosti (aktivistický). V některých přístupech je zřejmý sklon ke konkrétním potřebám trhu práce (polytechnický), u jiných jde spíše o obecněji pojaté gramotnosti (esencialistický).

Dimenzí, která může být lidmi pěstujícími určitý vědecký obor (v našem př́ípadě fyziku) nebo jiný, např. umělecký, považována za zásadní a výchozí, je dimenze ob-

\footnotetext{
${ }^{2}$ Jazykové souvislosti pojmu kurikulum uvádí např. Průcha (2017: s. 236-237).
} 
sahová. Netriviální otázkou je, co z širokého oborového obsahu transformovat do kurikula - patří sem tzv. ontodidaktická transformace, tj. transformace obsahu fyziky jako vědy do kurikulárních dokumentů, včetně např. učebnic (viz např. Janík, 2009: s. 141). Je zřejmé, že obsahem vyučovacího oboru může být nakonec jen velmi omezená množina oborových poznatků. V rámci fyziky, ale nejen jí, jsme vystaveni různým dilematům a tlakům. Na jedné straně se fyzika dynamicky rozvíjí, takže poznatků rychle přibývá. Na druhé straně fyzika staví na historických poznatcích, např. klasické mechanice a klasické elektrodynamice. Je otázkou, jak ze „starých klasických“, ale i „nových kvantových, relativistických“, příp. dalších poznatků, vybrat vhodný kurikulární obsah. Způsobů, jak se o to pokusit, je zřejmě více. Patrně nikdo nebude zpochybňovat, že výběr obsahu by měl být veden jasnými cíli, které ale mohou být voleny různě, a proto vidíme jako transparentní tyto cíle explicitně uvádět. Je zřejmé, že tyto cíle mohou odrážet zájmy různých lidí a jejich skupin, mohou se z různých úhlů pohledu jevit jako vhodné či nevhodné, mohou být poplatné době atd., nicméně jejich jasné formulování a zdokumentování, jak s nimi jednotlivé prvky obsahu kurikula souvisí, vidíme jako logický a transparentní prŕístup.

Jak bylo uvedeno výše, kurikulum lze vymezovat a chápat různě. Pokud se ovšem zaměříme na školní vzdělávání v rámci určitého oboru (zde fyziky), nabývá na zvláštním významu tzv. organizační dimenze kurikula. Jedná se o to, že v daném státě, příp. jeho části, je školství v daném čase určitým zpơsobem organizováno. V dané geografické (a kulturní) oblasti a v jistém časovém intervalu existují určité typy škol a k nim se vztahující vzdělávací dokumenty. V současné době v České republice sem mimo jiné patří zejména rámcové vzdělávací programy a na základě nich vytvořené školní vzdělávací programy. Pro snahy vytvořit a prosadit inovované kurikulum je podstatné (a limitující), že nové kurikulum by mělo v dané době závazné dokumenty vzdělávací politiky respektovat, př́íp. by se autoři měli snažit, aby ze vzniklého nesouladu nevyplynuly nežádoucí konsekvence. Domníváme se, že je rozumné, aby organizační dimenze byla podřízena ideové a obsahové dimenzi. Je ovšem otázkou, zda tomu tak skutečně je a zda nedochází k nežádoucím deformacím kurikula kvůli jeho předem dané organizaci a vůbec organizaci celého školského systému (viz oddíl 3.4).

Přímé působení učitele na žáka je součástí metodické dimenze. V rámci ní dochází k psychodidaktické transformaci (viz např. Janík, 2009: s. 141), tj. kurikulum obsažené např. ve vzdělávacích programech, ale také v metodických příručkách a učebnicích, je transformováno do obsahu výuky. Obecněji může jít samozřejmě o působení vzdělavatele (např. lektora v science centru) na vzdělávajícího se (např. dítě $\mathrm{v}$ předškolním věku). Tato dimenze tedy úzce souvisí s formami a metodami výuky (vzdělávání), prostřednictvím kterých má být dosaženo stanovených vzdělávacích cílů. Je zcela zřejmé, že velmi závisí na přistupu konkrétního učitele, jak výuka proběhne. Potenciál sebelépe připraveného kurikula (jeho ideová, obsahová a organizační dimenze) tak může zůstat nevyužit a neproměněn, na druhou stranu může být přidaná hodnota metodické dimenze díky kvalitnímu učiteli veliká, a tím pádem může připravené kurikulum konstruktivně využít.

\subsection{FORMY KURIKULA}

Předcházející stručný přehled dimenzí kurikula naznačuje, že určitá část kurikula je někdy úžeji spjata s jeho plánováním (promýšlením) - na něj výrazně odkazuje ideová dimenze kurikula, jindy spíše s realizací kurikula - zejména metodická a organizační dimenze. V odborných publikacích se v této souvislosti hovoří o formách, 
př́p. rovinách kurikula (srov. Maňák \& Janík, 2009: s. 119). V rámci výzkumů TIMSS (Mullis \& Martin et al., 2013: s. 4-6) jsou pak v této souvislosti rozlišeny tř́i roviny kurikula - zamýšlené (intended), realizované (implemented) a dosažené (attained) kurikulum. V podstatě představují časovou osu, kdy kurikulum prochází cestou od zrodu v ideové podobě, přes jeho uskutečňování (typicky výuka daného vzdělávacího oboru) až ke změnám u žáků (v kognitivní, afektivní oblasti atd.). Podrobněji k tomu uvádí Průcha, Walterová a Mareš (2013: s. 103) následující formy existence obsahu vzdělávání: koncepční, projektovou, realizační, rezultátovou a efektovou formu.

Koncepční forma zahrnuje zejména představy o tom, co má být obsahem vzdělávání (např. vzdělávacího oboru fyzika). Patří sem zejména dokumenty státní školské politiky, v současné době v České republice především rámcové vzdělávací programy ( $R V P Z V, 2017$ aj.), ale mohou sem také patřit koncepce vytvořené různými zájmovými a profesními skupinami lidí (v souvislosti s fyzikou např. představy fyziküvědců ohledně obsahu školské fyziky). Projektová forma kurikula konkretizuje formu koncepční, a to zejména prostřednictvím učebnic a školních vzdělávacích programů konkrétních škol. Realizační forma kurikula pak představuje učivo, které je učitelem při konkrétní výuce $\mathrm{v}$ dané třídě (nebo jiným vzdělavatelem) zprostředkováno žákům. Rezultátová forma zahrnuje vzdělávací výsledky učících se osob (např. výsledky učení se žáků, které jsou typicky zjištovány v písemných pracích v poměrně krátké době po skončení příslušné výuky). Při zjištování výsledků vzdělávání je však možné zaměřit se více na budoucnost a zajímat se o dlouhodobé důsledky vzdělávání. Tyto projevy v postojích, politické orientaci, kulturním zaměření apod. bývají zahrnovány pod tzv. efektovou formu kurikula. Další práce, které budou bezprostředně navazovat na tuto studii, se budou zabývat zejména koncepční a dále projektovou formou kurikula (více v závěru a diskusi).

Vzhledem k tomu, že některá vymezení pojmu kurikulum zahrnují obsah veškeré zkušenosti, kterou žáci získávají nejen ve škole, ale i v činnostech, které se ke škole vztahují, je třeba připustit, že do vzdělávání mohou významně promlouvat jevy a okolnosti, které nejsou plánované. Ty spadají do tzv. skrytého kurikula (Maňák \& Janík, 2009: s. 119). ${ }^{3}$ To zahrnuje např. klima tř́dy a školy, rozvrh hodin, charakteristiky učitele, které se projevují při jeho interakci se žáky, a mnohé další.

\subsection{SPECIFIKA FYZIKÁLNÍHO KURIKULA}

Charakteristiky kurikula uvedené v předcházejících oddílech se obecně týkají jakéhokoliv vzdělávacího oboru. Zaměřme nyní pozornost na fyzikální kurikulum. To má pochopitelně některá specifika. Jeho první specifikum je dáno tím, že samotný mateřský obor, fyzika, je součástí širši skupiny př́rodních věd. ${ }^{4} \mathrm{Z}$ toho vyplývá, že také fyzikální vzdělávání (a kurikulum) je součástí šiřreji pojatého př́rodovědného vzdělávání, resp. kurikula. Ve vzdělávací praxi pak v souvislosti s tímto faktem dochází $\mathrm{k}$ tomu, že fyzika jako vzdělávací obor je více nebo méně integrována s výukou dalších př́rodovědných oborů (srov. Hejnová, 2011). V této souvislosti poznamenejme, že nemusí jít jen o integrování př́rodovědných poznatků (faktů), ale také např. metod, jakými př́rodovědné obory $\mathrm{k}$ poznatkům dospívají.

Dalším charakteristickým rysem, který je specifický pro fyziku, je její značná matematizace. Pochopitelně také další přírodní vědy, ale i obory socio-humanitní, vyu-

\footnotetext{
${ }^{3}$ Naopak výše uvedené formy a dimenze se týkají tzv. formálního kurikula.

${ }^{4} \mathrm{~V}$ dalším textu budeme místo termínů přírodovědné obory, přírodní vědy používat také termín science.
} 
žívají matematický aparát (zejména ve fázi vyhodnocování získaných dat), nicméně pro fyziku je intenzivní využivání matematiky zcela zásadní (a koneckonců i historicky dané). Fyzika je tedy z podstaty integrována s matematikou (dále viz oddíl 3.3).

Zatímco výše uvedená specifika jsou spíše ontodidaktické povahy (jsou spojena zejména s podstatou fyziky jako vědeckým oborem, jejím obsahem), následující specifikum můžeme asociovat spíše s psychodidaktickým rozměrem. Ze zkušenosti mnoha učitelů, ale také z výzkumných zjištění vyplývá, že fyzika patří mezi (nej)méně oblíbené předměty ve školách (např. Hrabal \& Pavelková, 2010: s. 31-33).

Specifik fyzikálního kurikula je možné samozřejmě nalézt více. Smyslem připomenutí několika z nich je naše přesvědčení, že proměna fyzikálního kurikula (tvorba nového) by měla mít tato specifika na zřeteli. Závěrem prvního oddílu ještě uvedme, že kladení si podstatných otázek souvisejících s kurikulem není něčím novým, ačkoliv např. termín kurikulum zmíněn není (Fenclová, 1984: s. 15):

„Co však si mají z výuky fyziky odnést? Znalost pojmů a zákonů, teorií, principů, či představu o hlavních idejích fyziky a o mechanistickém, elektromagnetickém a moderním obrazu světa? Nebo mají spíše chápat cesty poznávání ve fyzice a metody práce fyziků? Lze žáky provádět historickým vývojem fyziky? Mají fyziku vidět spíše jako vědu přírodní či laboratorní? Má být fyzika pro žáky spíše lehká a zábavná, či obtížná a vznešená? Jsou pro žáky nutné znalosti z moderní fyziky? Jak se lze vyrovnat s explozí fyzikálního poznání? S kolika aplikacemi fyziky se žáci mají seznámit a s kterými? Co zařadit do všeobecného vzdělání žáka, který se už s fyzikou nikdy nesetká? Tyto a další otázky si kladou vědci a tvůrci didaktických systémů i projektů, odpovědi na ně nejsou lehké ani jednoznačné. I učitel by si na ně měl odpovědět, protože jeho práce a zdůrazňování některých aspektů často nejvýrazněji ovlivní učení žáků a jejich vzdělání."

\section{Metodologie}

Z metodologického hlediska byl k dosažení stanoveného cíle použit v podstatě kvalitativní př́stup. ${ }^{5}$ Data byla sbírána na základě analýzy odborných publikací. Záměrem je analyzovat publikace, které se zabývají problematikou proměn (reformování) kurikula a speciálně metodami, kterými byl vymezen příslušný kurikulární obsah, zejména ideová a obsahová dimenze. Možných zdrojů, ze kterých lze čerpat, existuje samozřejmě mnoho, a tudíž bylo nutné se zaměřit pouze na některé z nich. Protože předpokládáme, že studie zabývající se kurikulem jsou ve většině případů nakonec publikovány časopisecky, zaměřili jsme se na analýzu databází, jejichž součástí jsou časopisy, které publikují články z oblasti physics education research (PER). Dosavadní rešerše se zatím omezila na mezinárodní databáze SCOPUS $^{6}$ a Web of Science ${ }^{7}$ a vývoj počtů dosud vyhledaných relevantních publikací je zachycen v tab. 1 . Považujeme za účelné provést rešerši jak mezinárodních zdrojů (u kterých lze očekávat, že většina z nich bude zahraničních), tak zdrojů domácích. Protože můžeme předpokládat, že mezinárodních zdrojů bude více a budou více diskutovány (vzhledem k širšímu okruhu potenciálních čtenářro ), byla první fáze rešerše věnována právě me-

\footnotetext{
${ }^{5}$ Odkazujeme se ke kvalitativnímu přístupu, i když je z následujícího patrné, že výsledky rešerše jsou částečně vyjádřeny kvantitativně (počty prací v tab. 1). Podstatou ovšem je, že byla identifikována určitá kvalitativní zjištění (viz oddíl 3).

${ }^{6}$ Dostupné z https://www.scopus.com/

${ }^{7}$ Dostupné z https://webofknowledge.com/
} 
Tab. 1: Počty identifikovaných relevantních publikací v databázích SCOPUS a Web of Science

\begin{tabular}{lcc}
\hline Počet publikací nalezených v časovém rozmezí listopad & SCOPUS & Web of Science \\
2016 až březen 2017 & & \\
\hline na základě klíčových slov a dalších filtrů & $250^{*}$ & $200^{*}$ \\
na základě názvu & $80^{*}$ & $60^{*}$ \\
na základě abstraktu & 29 & 13 \\
\hline
\end{tabular}

*Počty publikací jsou zaokrouhleny na desítky.

zinárodním zdrojům. Rešerše domácích zdrojů bude součástí navazujících studií. Je třeba upozornit na to, že teprve podrobný rozbor jednotlivých výzkumných nálezů a jejich kontextu může ukázat, která z těchto zjištění budou využitelná v kontextu fyzikálního vzdělávání v České republice.

Relevantní publikace byly v databázích vyhledávány pomocí několika různých kombinací klíčových slov a dalších filtrů, kterými se vždy omezil počet článků na přibližně padesát, což jsme si předem stanovili jako ještě únosný počet. Jinak by bylo vyhledaných publikací, které by bylo potřeba prozkoumat, př́liš mnoho a jejich analýza by byla extrémně časově náročná. Takto identifikované články byly pak dále tříděny na relevantní a nerelevantní na základě obsahové analýzy nejprve jejich názvi̊ a poté abstraktů. Při tom nebyl využiván žádný specializovaný software.

Jako klíčová slova (př́ípadně sousloví) pro vyhledávání v databázích byly zvoleny následující termíny: physics, science, curriculum, curriculum reform, curriculum design, secondary school. Tato klíčová slova byla v publikacích vyhledávána $\mathrm{v}$ př́padě databáze SCOPUS v oddílu (pomocí filtru) abstract nebo article title. V databázi Web of Science byl využit oddíl topic.

Filtry, kterými se dále omezoval výběr publikací, byly v případě databáze SCOPUS: article or review; physical sciences; social sciences $\&$ humanities a časové rozpětí 2000 to present. V průběhu rešerše však došlo ke změně internetové stránky databáze SCOPUS, a tím pádem i k úpravě způsobu vyhledávání v databázi. Po změně se mírně lišily filtry, kterými se omezoval výběr publikací. Nově byly využity tyto filtry: article; review; physics and astronomy; social sciences, časové rozpětí zůstalo stejné. V databázi Web of Science byly těmito filtry: article; review; education \& educational research.

Z publikací, které byly identifikovány výše zmíněným způsobem, byly následně vyřazeny takové, jejichž název napovídal, že nebudou obsahovat relevantní informace. Zejména se jednalo o publikace, které se věnovaly pouze vybraným fyzikálním tématům (např. se často objevovalo téma elektromagnetické indukce), přičemž v centru našeho zájmu byl spíše komplexnější pohled na fyzikální kurikulum (a zejména na jeho obsahovou dimenzi). ${ }^{8}$ Jiné publikace byly zaměřeny např. na genderové otázky spojené s fyzikou a oblastí science, ale vůbec nereflektovaly obsahovou dimenzi kurikula.

U publikací, které nebyly tímto způsobem vyřazeny na základě názvu, byly dále analyzovány abstrakty, na jejichž základě bylo vyřazeno další poměrně velké množství článků. Po prostudování abstraktů se ukázalo, že se mnohé zabývají spíše vý-

\footnotetext{
${ }^{8}$ Relativně vysoký počet prací zaměřených na začlenění určitého fyzikálního nebo interdisciplinárního tématu do kurikula a přitom nízký počet prací, které se kurikulem zabývají komplexněji, byl identifikován v disertačních pracích z didaktiky fyziky, které byly obhájeny v Ceské republice (podrobněji Žák, 2015: s. 42).
} 
sledky, které přinesla proměna kurikula v porovnání s předchozím stavem, ale bohužel neuvádějí procedury a důvody, díky kterým se dospělo ke konkrétní podobě nového kurikula. Publikace, které nebyly vyřazeny, nebyly ještě ale prostudovány všechny a výsledky uvedené v této studii nejsou úplné (viz název studie).

Je zřejmé, že výše uvedený zpo̊sob vyhledávání relevantních publikací není vyčerpávající a jediný možný. Tento proces bude proto dále pokračovat. K vyhledávání se nabízejí další databáze informačních zdrojů, např. ERIH PLUS a Google Scholar. V úvahu připadá také rozsáhlejší analýza časopisů specializovaných na kurikulum, např. Curriculum Journal (přehled časopisů relevantních pro oblast physics education research viz Žák, 2016: s. 32-33). Pozornost bude také věnována knižním publikacím mimo uvedené databáze.

\section{VÝSLEDKY}

Na základě výše popsané rešerše bylo v publikacích, které se ukázaly jako relevantní, identifikováno několik zjištění, která by mohla ovlivnit úvahy o proměnách fyzikálního kurikula. Každému z těchto zjištění je níže věnován samostatný oddíl. Na druhou stranu se nejedná o úplný výčet všech možných podnětů, které z rešerše vzešly. Oddíly jsou řazeny na základě významnosti zjištěných skutečností od nejdůležitějších po ty méně významné (dle našeho názoru).

\subsection{Nedostatek RELEVANTNích PUblikací}

První, čeho si lze všimnout v tab. 1, je poměrně malý počet publikací, které se podle abstrakti̊ jeví jako relevantní. Zdá se, že v časopisech z databází SCOPUS a Web of Science je od roku 2000 publikováno pouze velmi omezené množství článků (příp. nelze je př́močaře dohledat), které by popisovaly způsoby, jakými se dospělo ke konkrétním proměnám kurikula fyziky nebo případně celé oblasti science. Zřejmě to souvisí s problémem nedostatečné pozornosti, která je kurikulu na mezinárodní scéně věnována. Lze sice dohledat mnoho článků, které se věnují jedné konkrétní části fyzikálního kurikula (jeho obsahu), např. se velmi často objevují inovace vztahující se $\mathrm{k}$ výuce elektromagnetické indukce, různých částí termodynamiky a také Newtonových pohybových zákonů, ale jen obtížně je možné nalézt publikace, které by braly v potaz širší souvislosti, např. co všechno z hlediska fyzikálního obsahu by mělo být vyučováno a z jakých důvodů, jakou filozofickou oporu toto rozhodnutí má (by mělo mít), jakým způsobem by měl být daný obsah do výuky začleněn atd. Na nedostatek pozornosti, která by se orientovala tímto směrem, je v mezinárodní literatuře opakovaně upozorňováno (např. Schneider, Krajcik \& Marx, 2000: s. 56; Sheppard \& Robbins, 2003: s. 420; Grayson, 2006: s. 31). Schneider, Krajcik a Marx (2000) zmiňují téměř chybějící výzkum v oblasti vytváření materiálů pro učitele, kam spadají i učebnice.

Na druhou stranu se podařilo nalézt relativně velké množství článků (vzhledem k celkovému počtu článků, které se věnují fyzikálnímu kurikulu a kurikulu oblasti science), které se na první pohled jeví jako relevantní a u kterých se zdá, že se věnují proměnám (reformám) obsahu kurikula fyziky komplexněji. Ve zkoumaném období od roku 2000 až po současnost vyšlo několik publikací, které popisují reformu základního kurzu (a prř́padně i dalších kurzů) fyziky na univerzitách. V centru naší pozornosti sice proměny kurikula fyziky na vysokoškolské úrovni nestojí, nicméně i tyto publikace mohou obsahovat cenné informace, které budou potenciálně využi- 
telné. Může jít např. o metodologii, která byla využita při tvorbě nového kurikula, zejména jeho obsahové dimenze, na kterou se budeme zaměřovat. Bohužel podrobnější studium těchto publikací ukazuje, že tomu tak většinou není. Nalezené časopisecké články jsou typicky kvantitativně zaměřeny a porovnávají výsledky studentů v daných kurzech před reformou a po ní. Chybí však podrobnější diskuse důvodi̊, které vedly k reformě kurikula, a dále absentují informace o tom, jak byla provedena, na základě idejí kterých autorit či myšlenkových proudů atd.

\subsection{PROMĚNA KURIKULA NA ZÁKLADĚ MALÝCH ZMĚN PŘEDCHOZÍHO KURIKULA}

Na základě zjištění vzešlých z dosavadní rešerše se zdá, že proměny (reformy) kurikula fyziky často probíhají formou mírných úprav kurikula předcházejícího a jeho obsah je v podstatě již předem dán tradicí (např. Cheung \& Ng, 2000: s. 369; Carlone, 2003: s. 325; Grayson, 2006: s. 36). Tradiční obsah se objevuje zejména u akademického př́stupu (viz dimenze kurikula, oddíl 1.2), kde se žáci na středních školách učí důležité fyzikální zákony a teorie a obvykle jsou v učebním procesu spíše pasivní (Cheung \& Ng, 2000: s. 359). Během rešerše byly identifikovány inovativní př́istupy právě jako reakce na tradiční fyzikální kurikulum, např. Active Physics, za kterým stojí Stewart a Carpenterová. Active Physics vznikla relativně izolovaně od běžné školské fyziky, což je možná hlavní důvod, proč mohl vůbec tento nový směr vzniknout. Díky izolaci nebyla Active Physics př́liš ovlivněna názory, které jsou spíše v souladu s tradiční fyzikou (Carlone, 2003: s. 325).

\subsection{ProblÉmy SPOJENÉ S MATEMATIZACÍ FYZIKY}

Úroveň matematických znalostí a dovedností žáků učících se fyziku na středních školách je jako problém uváděn drtivou většinou nalezených publikací. Uváděny jsou názory studenti̊, ve kterých se objevuje matematika jako jedna z příčin jejich nezájmu a někdy téměř až odporu k fyzice; studenti pokládají fyziku za př́liš abstraktní a matematickou (např. Sheppard \& Robbins, 2003: s. 422). Názor, že je fyzika příliš matematizována, se objevuje také mezi učiteli (Carlone, 2003: s. 318; Sheppard \& Robbins, 2003: s. 423). V souvislosti s názory učitelů (obecně, ne nutně fyziky) se také ale objevuje zarážející myšlenka, že fyzika není fundamentální vědou, že není důležitá pro pochopení poznatků z dalších vědeckých oborů a že je určena pouze pro matematicky nadanou, akademickou elitu (Sheppard \& Robbins, 2003: s. 423). Přirozeně se objevují i opačné názory, a sice, že fyzika je důležitá a vhodná k osvojení si dovedností pro fungování v moderním světě (Grayson, 2006: s. 36), a také matematika je mnohými pokládána za důležitou část fyziky (Hestenes, 2003: s. 105; Grayson, 2006: s. 33).

Výše uvedený problém s matematickou úrovní žáků není vnímán pouze jako problém středoškolské úrovně, ale podobné potíže se zřejmě vyskytují i na univerzitách. Na vysoké škole však už prakticky není možné matematiku ve fyzice obejít, i když samozřejmě pochopení fyzikálních konceptů (spíše kvalitativní povahy) je i zde do̊ležité. Jelikož se fyzikální teorie opírají o matematický popis, nepřekvapuje názor, že by měla být matematice věnována ve fyzikálním kurikulu speciální pozornost (Hestenes, 2003: s. 105).

Problém s matematizací fyziky je také zřejmě spojen s upadajícím zájmem o studium fyziky - mezi žáky středních škol se fyzika často objevuje jako jeden z nejméně oblíbených předmětů, obdobně matematika (srov. Riess, 2000: s. 328, srov. Hrabal 
\& Pavelková, 2010: s. 31-33, viz oddíl 1.4). V souvislosti s tím se také objevují inovativní směry a aktivity, ve kterých je kladen větší důraz na fyzikální koncepty a kvalitativní interpretaci fenoménů než na matematickou rigoróznost (Carlone, 2003: s. 318; Grayson, 2006: s. 32), i když ani zde není opomíjen fakt, že matematika je pro fyziku velmi důležitá.

\subsection{DŮlEŽITOST ORGANIZAČNí DIMENZE KURIKULA}

Jak bylo uvedeno výše, naše pozornost je zaměřena zejména na ideovou a obsahovou dimenzi kurikula. Jak ale ukazují některé studie, nebylo by vhodné zaměřit se výlučně na tyto dvě dimenze a ostatní opomíjet.

Jak uvádějí Sheppard a Robbins (2003: s. 421), na středních školách v USA se organizační dimenze kurikula (viz oddíl 1.2) výrazně promítá do zájmu žáků o fyziku. Kromě problémů s matematikou, kterou žáci při studiu fyziky potřebují a která snižuje atraktivitu fyziky, se v USA na středních školách ukazuje jako limitující kreditový systém. Aby mohl žák pokračovat ve studiu na vysoké škole, musí získat alespoň jeden kredit z předmětů z oblasti science, tj. z biologie, chemie nebo fyziky. Protože je biologie pro žáky relativně atraktivní (resp. zapisují se do biologických předmětů - viz Sheppard \& Robbins, 2003: s. 423) a je z prŕrodovědných předmětů vyučována (resp. nabízena jako předmět) v pořadí jako první, žáci typicky získají potřebný kredit právě z biologie, zatímco chemie a fyzika se stávají v podstatě volitelnými předměty. Dá se říci, že takováto organizace předmětů z oblasti science přímo vede $\mathrm{k}$ upadajícímu zájmu žáků o fyziku.

\subsection{PotřebA TEORIE A FILOZOFIE VZDĚLÁVÁNí}

Při rešerši mezinárodních publikací se podařilo identifikovat práce, které jsou k současnému kurikulu oblasti science velmi kritické, a stejně tak i ke způsobům, jakým je kurikulum běžně utvářeno. Některými autory jsou realizované proměny kurikula označovány za utilitární, tj. při hledání cílů (viz ideová dimenze) se zanedbávají potřeby vzdělávání jednotlivce a upřednostňují se spíše požadavky společnosti a potřeby profesionální praxe (srov. oddíl 1.2, např. Schulz, 2009: s. 228). Stručně můžeme říci, že se v první řadě hledá odpověd’ na otázku: „K čemu jsou lidé v oblasti science vzděláváni?" Dále je také kritizováno, že je výzkum v oblasti přírodovědného vzdělávání př́liš ovlivněn jinými obory, zejména psychologií, filozofií a sociologií (Schulz, 2009: s. 226, 243).

Aby se výzkum vzdělávání, spec. vzdělávání v oblasti science, oprostil od případných překážek, které jsou spojeny s dalšími obory, zejména s psychologií, měla by vzniknout speciální „teorie vzdělávání“ (resp. „teorie vzdělávání v oblasti science“) jako samostatný obor a s ním by měla být propracována související filozofie vzdělávání (Schulz, 2009: s. 226). Při reformách kurikula by se potom hledaly odpovědi na otázky vycházející z této teorie a ne z jiných oblastí. K odklonu od utilitárnosti by mělo pomoci to, že nejzákladnější otázkou bude: „Co znamená být vzdělán?“, resp. „Co znamená být vzdělán v oblasti science?", a otázka, „K čemu získané vzdělání bude?", má být až druhotná (Schulz, 2009: s. 228).

\section{ZÁVĚR A DISKUSE}

Pojmu kurikulum jsou v odborné literatuře přisuzovány různé významy. Patří k nim zejména obsah vzdělávání, vzdělávací plán a nejobecněji obsah veškeré zkušenosti, 
kterou žáci získávají ve škole a v činnostech ke škole se vztahujících. O různých významech a složitosti pojmu kurikulum vypovídají jeho dimenze - ideová, obsahová, organizační a metodická. Kurikulum existuje také v různých formách - koncepční, projektové, realizační, rezultátové a efektové.

Pokud jde o dimenze kurikula, naší ambicí je zaměřit se na ideovou a obsahovou dimenzi. Vzhledem k tomu, že naším záměrem je zjistit mimo jiné názory odborníků, kteří rozvíjejí fyziku jako obor, tj. názory fyziků, je přirozené, že obsahové dimenzi se nelze vyhnout. Mưžeme předpokládat, že fyzikální obsah bude tvořit páteř jejich úvah o fyzikálním kurikulu. V souvislosti s tím vidíme ovšem jako podstatné zjištovat, z jakého důvodu považují za důležité tito respondenti určitý prvek fyzikálního obsahu do kurikula zahrnout. Tím se tedy dostáváme k ideové dimenzi kurikula.

Organizační dimenze je do značné míry dána školským systémem, tj. je poměrně obtížné ji z perspektivy fyzikálního kurikula, jako jednoho z kurikul, významněji změnit. Vzhledem k tomu, že do organizační dimenze kurikula spadají mimo jiné rámcové vzdělávací programy a další školské dokumenty, které strukturují výuku fyziky na různých stupních vzdělávání, můžeme k dilematům, která se k této dimenzi kurikula vztahují, zařadit např. otázku, zda má být fyzika a další vzdělávací obory odpovídající vědeckým disciplínám vyučována ve dvou (nebo dokonce více) cyklech, tj. zda má kurikulum fyziky pro základní školu zahrnovat všechny podstatné poznatky a středoškolské kurikulum má na vyšší úrovni tyto poznatky opět pojímat a rozvíjet. Alternativou je např. př́istup, kdy středoškolské kurikulum pro různé typy škol výrazně zohledňuje jejich specifika, což by se odráželo ve výběru prvků těchto kurikul. Zejména u škol s nízkou hodinovou dotací fyziky je tato otázka naléhavá. Konečně metodická dimenze úzce souvisí s učebnicemi a jejich využiváním žáky a učiteli. Právě tvorba nových učebnic fyziky opřená o řešení důležitých otázek spojených s kurikulem má představovat významný krok, který by měl pozitivně ovlivnit běžnou výuku fyziky ve školách.

Dosavadní rešerše naznačuje, že bude nutné zohlednit všechny dimenze kurikula, i když se budeme zaměřovat především na ideovou a obsahovou dimenzi, jak je uvedeno výše. Jak se ukazuje, existují př́ipady, ve kterých organizační dimenze v podstatě zastínila ostatní a obsahová dimenze by se organizační měla zřejmě v těchto případech přizpůsobit, aby se změnila situace se zájmem žáků o fyziku (např. v USA by bylo zřejmě nutné, s přihlédnutím k organizační dimenzi kurikula, volit obsahovou dimenzi kurikula fyziky atraktivní hlavně pro žáky - jinak budou mít jen málo důvodů, aby se do fyzikálních kurzů zapisovali).

Z rešerše dále vyplývá, že při naší snaze hledat alternativní ideovou a obsahovou dimenzi kurikula bude $\mathrm{k}$ dispozici pouze omezené množství zdrojů, kterými bychom se mohli inspirovat nebo se vưči nim jinak vymezit. Budeme tedy zřejmě nuceni být více tvưrčí, než bylo zprvu naším záměrem. Jak bylo zmíněno výše, oproštění se od typických postupů a jistá míra nevázanosti, resp. odstupu od zastánců tradičního pojetí výuky fyziky (byt’ o pojmu tradiční pojetí mohou mít různí lidé různé představy), může být dobrým předpokladem pro vznik nového kurikula. V opačném př́ípadě hrozí riziko, že tlak na prosazení tradičního pojetí výuky fyziky bude tak silný, že v konečném důsledku žádná nová alternativa $\mathrm{k}$ současnému fyzikálnímu kurikulu nevznikne.

Z hlediska forem kurikula je zřejmé, že výše uvedené zjištování názorů fyziků (ale také zástupců dalších skupin lidí, např. jiných př́rodovědců) a zamýšlená tvorba učebnic fyziky se budou týkat zejména koncepční a projektové formy kurikula.

Casto zmiňovaný problém s matematikou a s její úrovní nás vede k přesvědčení, že matematické kurikulum by mělo být významným faktorem při tvorbě nového 
fyzikálního kurikula. Ačkoliv se nejedná přímo o druh informace, kterou jsme hledali (tedy jakým zpo̊sobem tvořit nové fyzikální kurikulum), jsme přesvědčeni, že je tato skutečnost velmi důležitá (vzhledem $\mathrm{k}$ frekvenci, s jakou je uváděna) a bude nutné na ni brát ohled při dalším postupu, tj. při hledání inovovaného obsahu fyzikálního kurikula. Přihlédne-li se ovšem k názorům žáků nejen na fyziku, ale i na matematiku, prosté přizpůsobení se matematickému kurikulu by zřejmě nebyl rozumný postup. Takováto alternativní školská fyzika by vzhledem k oblíbenosti současné matematiky žáky spíše od studia fyziky odradila, což je nežádoucí efekt, který si od inovovaného kurikula fyziky neslibujeme.

Předchozí úvahy nás vedou k myšlence, že by zřejmě bylo vhodné inovovat fyzikální kurikulum při současném reformování kurikula matematiky, které by mohlo být vhodným způsobem zkombinováno s fyzikálním kurikulem. Tím rozhodně nechceme říct, že by mělo být matematické kurikulum prostě přizpůsobeno fyzikálnímu a že mu má být snad podřízeno. Ovlivnění by zřejmě mělo být oboustranné, aby se dospělo k co nejorganičtějšímu systému matematika-fyzika. Neděláme si ovšem ambice, že bychom mohli při našich prvních snahách o proměnu fyzikálního kurikula dosáhnout ihned tohoto systému. V první řadě se budeme zaměřovat na fyzikální problematiku, ale $\mathrm{v}$ souvislosti s ní se mohou objevit také podněty pro inovace kurikula matematiky.

K identifikovaným názorům, které kritizují dosavadní postup proměn fyzikálního kurikula, jsme spíše skeptičtí. Podle našeho mínění jsou tyto názory relativně radikální a nemůžeme říct, že bychom se s nimi úplně ztotožňovali. Některé myšlenky pro nás budou při dalším postupu zřejmě nosné, např. otázka „Co znamená být vzdělán v oblasti přírodních věd?", ale rozhodně nezavrhujeme dosavadní způsoby vytváření kurikula a budeme $\mathrm{v}$ nich hledat inspiraci, př́ipadně se vůči nim vymezovat. Jsme přesvědčeni, že kurikulum je ovlivněno takovým množstvím faktorů, že v podstatě nelze vybrat ideální metodologii jeho reformování, příp. tvorby. Např́klad velmi záleží na přístupu učitele (Cheung \& Ng, 2000: s. 357), který žákům dané kurikulum zprostředkovává (nebo spíše jeho část - vzhledem k širokému záběru pojmu kurikulum), a je-li o jeho smyslu přesvědčen, bude ho schopen zřejmě efektivně zprostředkovat.

Další práce, které budou bezprostředně navazovat na tuto studii, se budou zabývat zejména koncepční a dále projektovou formou kurikula. Na základě provedené rešerše se pokusíme navrhnout metodologii, kterou bude možné zjistit, jaké představy o obsahu a cílech fyzikálního vzdělávání mají relevantní aktéři z oblasti fyziky (resp. přírodních věd) a z oblasti vzdělávání v těchto oborech. Podle našeho názoru se mezi relevantní aktéry řadí zejména přírodovědci (především fyzikové), experti z technické praxe, didaktici přrírodovědných oborů a učitelé. Předpokládáme využití kvalitativního př́stupu a interview jako metody sběru dat. Dále předpokládáme, že nastíněný postup bude upřesněn, příp. modifikován na základě pokračující rešerše.

\section{LITERATURA}

Carlone, H. B. (2003). Innovative science within and against a culture of "achievement". Science Education, 87(3), 307-328.

Cheung, D. \& Ng, P.-H. (2000). Science teachers' beliefs about curriculum design. Research in Science Education, 30(4), 357-375.

Fenclová, J. (1984). Didaktické myšlení a jednání učitele fyziky: Cvičení z didaktiky fyziky. Praha: Státní pedagogické nakladatelství. 
Grayson, D. J. (2006). Rethinking the content of physics courses. Physics Today, 59(2), $31-36$.

Hejnová, E. (2011). Integrovaná výuka přírodovědných předmětů na základních školách v českých zemích - minulost a současnost. Scientia in educatione, 2(2), 77-90.

Henderson, J. G. (1996). Reflective teaching. Englewood Cliffs: Merrill.

Hestenes, D. (2003). Oersted medal lecture 2002: Reforming the mathematical language of physics. American Journal of Physics, 71(2), 104-121.

Hrabal, V. \& Pavelková, I. (2010). Jaký jsem učitel? Praha: Portál.

Janík, T. (2009). Obsah vzdělávání. In J. Průcha (Ed.), Pedagogická encyklopedie (138-142). Praha: Portál.

Maňák, J. \& Janík, T. (2009). Kurikulum. In J. Průcha (Ed.), Pedagogická encyklopedie (117-121). Praha: Portál.

Mullis, I. V.S. \& Martin, M. O. (Eds.). (2013). TIMSS 2015 Assessment frameworks. Chestnut Hill: TIMSS \& PIRLS International Study Center.

Ornstein, A. C. \& Levine, D. U. (1989). Foundations of education. Boston: Hougton Mifflin Co.

Průcha, J. (2017). Moderní pedagogika. Praha: Portál.

Průcha, J., Walterová, E. \& Mareš, J. (2013). Pedagogický slovník. Praha: Portál.

Riess, F. (2000). Problems with German science education. Science and Education, 9(4), $327-331$.

Roth, L. (Ed.). (1991). Pädagogik - Handbuch für Studium und Praxis. München: Ehrenwirth.

RVP ZV. Rámcový vzdělávací program pro základní vzdělávání. (2017). Praha: MŠMT. Dostupné z http://www.nuv.cz/uploads/RVP_ZV_2017_cerven.pdf

Sheppard, K. \& Robbins, D. M. (2003). Physics was once first and was once for all. Physics Teacher, 41(7), 420-424.

Schneider, R. M., Krajcik, J. \& Marx, R. (2000). The role of educative curriculum materials in reforming science education. In B. Fishman \& S. O'Connor-Divelbiss (Eds.), Fourth international conference of the learning sciences (54-61). Mahwah, NJ: Erlbaum.

Schulz, R. M. (2009). Reforming science education: Part I. The search for a philosophy of science education. Science and Education, 18(3-4), 225-249.

Žák, V. (2015). Disertační práce z didaktiky fyziky obhájené v České republice v letech 2004 až 2013 - přehled a analýza. Scientia in educatione, 6(2), 35-50.

Žák, V. (2016). Metody sběru dat využívané didaktikou fyziky v mezinárodním prostředí. Scientia in educatione, 7(2), 18-33.

VoJTĚCH ŽÁK, Vojtech.Zak@mff.cuni.cz

Petr KolÁŘ, Petr.Kolar@mff.cuni.cz

Univerzita Karlova, Matematicko-fyzikální fakulta

Katedra didaktiky fyziky

V Holešovičkách 2, 18000 Praha 8, Česká republika 